\title{
PENGARUH MOTIVASI DAN DISIPLIN KERJA TERHADAP KINERJA GURU SEKOLAH MENENGAH ATAS NEGERI 11 SIJUNJUNG
}

\author{
Hariman Syaleh \\ Sekolah Tinggi Ilmu Ekonomi Haji Agus Salim Bukittinggi \\ Jl. Ahmad Yani No.79, Bukit Apit Puhun, Guguk Panjang, Kota Bukittinggi \\ E-mail : harimansyaleh@yahoo.co.id
}

\begin{abstract}
This study aims to analyze the influence of work motivation and work discipline on the performance of teachers of State Senior High School 11 Sijunjung. Here the authors describe the effect of work motivation and work discipline on the performance of teachers in State Senior High School 11 Sijunjung. The number of population in this research is counted 24 people so that the entire population is made sample by using census method. Data were collected through questionnaire distribution with Likert scale model then tested to validity and reliability of the questionnaire. Data analysis technique used is multiple linear regression method using SPSS 20.00 program. The purpose of multiple linear regression to see the relevance of the influence of independent variables to the dependent variable. The result of this research is a). Motivation of work (X1) there is a positive and significant influence on the performance of teachers at State Senior High School 11 Sijunjung. b). Work discipline (X2) there is a positive and significant influence on the performance of teachers at State Senior High School 11 Sijunjung. c). Then Motivation work and Discipline work together - there is a positive and significant influence on the performance of teachers at State Senior High School 11 Sijunjung so that the hypothesis can be accepted.
\end{abstract}

Keywords: Motivation; Discipline; Performance

\section{PENDAHULUAN}

Salah satu hal yang mempengaruhi kinerja guru adalah disiplin. Prawirosentono (2009) mengemukakan teorinya bahwa mutu pekerjaan, ketelitian dan ketepatan pekerjaan merupakan hal yang perlu diperhatiakan di dalam organisasi ataudi lingkungan sekolah, seorang guru dalam memberikn pelajaran kepada para siswa harus tau sampai dimana kemampuannya dan juga kemampuan para siswa dalam menerima pelajaran yang diberikan guru, begitu juga dengan ketelitian seorang guru terhadap pelajaran yang di ajarkan kepada para siswa/i dan ketepatannya apakah pelajaran ini sudah pantas di ajarkan kepada para siswa/ i di Sekolah Menengah Pertama Negeri 11 Sijunjung. Karena tanpa adanya disiplin, maka segala kegiatan yang akan dilakukan akan mendatangkan hasil yang kurang memuaskan dan tidak sesuai dengan harapan. Hal ini dapat mengakibatkan kurangnya pencapaian sasaran dan tujuan organisasi atau perusahaan serta dapat juga menghambat jalannya program organisasi yang dibuat. Dalam sistem pendidikan nasional salah satu komponen yang saling menentukan keberhasilan pendidikan adalah guru.

Guru mempunyai peranan besar dalam proses kegiatan pembelajaran. Selain tenaga pengajar guru juga berfungsi sebagai pendidik yang mengarahkan sikap dan mental anak didik kearah yang lebih baik. Dengan berlakunya Undang-Undang Republik Indonesia No 20 tahun 2003 tentang sistem pendidikan nasional serta peraturan pemerintah sebagai pelaksanaannya. Sekolah Menengah Atas merupakan bagian integral dari sistem dan salah satu bentuk satuan pendidikan yang ada. 
Karena itu faktor disiplin sangat berpengaruh dan mempunyai peranan penting terhadap peningkatan kinerja guru. Jika dilihat secara riil, faktor kedisiplinan memegang peranan yang amat penting dalam pelaksanaan tugas sehari-hari para guru.

Seorang guru yang mempunyai tingkat kedisiplinan yang tinggi akan tetap bekerja dengan baik walaupun tanpa diawasi oleh atasan. Seorang guru yang disiplin tidak akan mencuri waktu kerja untuk melakukan hal-hal lain yang tidak ada kaitannya dengan pekerjaan. Guru yang profesional adalah guru yang mengedepankan mutu dan kualitas pendidikan, layanan guru harus memenuhi standarisasi kebutuhan masyarakat dan bangsa serta memaksimalkan kemampuan peserta didik berdasarkan potensi dan kecakapan yang dimiliki guru. Guru yang profesional harus memiliki beberapa kompetensi dalam undang undang guru dan dosen No 14 tahun 2005 Bab IV pasal 10 ayat 1 menjelaskan kompetensi yang harus dimiliki guru meliputi kompetensi kebribadian, kompetensi sosial, dan kompetensi profesional. Semua kompetensi tersebut harus dimiliki oleh seorang guru dalam menjalankan tugas dan tanggung jawabnya agar mempunyai motivasi kerja.

Demikian juga guru yangmempunyai kedisiplinan akan mentaati peraturan yang ada dalam lingkungan kerja dengan kesadaran yang tinggi tanpa ada rasa paksaan. Pada akhirnya guru yang mempunyai kedisiplinan yang tinggi akan mempunyai kinerja yang baik bila dibanding dengan para guru yang bermalas-malasan. karena waktu kerja tidak dimanfaatkannya sebaik mungkin untuk melaksanakan pekerjaan sesuai dengan target yang telah ditetapkan, jadi disiplin merupakan sebuah titik awal dari segala kesuksesan dalam rangka mencapaitujuan sebuah organisasi. Penerapan disiplin dalam suatu organisasi bertujuan agar semua pegawai yang ada dalam organisasi tersebut bersedia dengan sukarela mematuhi serta mentaati setiap tata tertib yang berlaku tanpa ada paksaan.

Disiplin yang baik dapat dilihat pada Sekolah Menengah Atas Negeri 11 Sijunjung dimana sekolah ini terletak jauh dari perkampungan sehingga untuk sampai kesekolah ini harus melalui jalan yang jauh tetapi meskipun seperti itu kinerja guru juga masih dapat dikatakan baik meskipun jauh dari perkotaan, sedangkan disiplin juga masih sudah berjalan sesuai dengan yang di harapkan meskipuan ada beberapa guru yang tidak disiplin, begitu juga dengan motivasi di sekolah kurang diperhatikan oleh kepala sekolah sehingga banyak para guru yang kurang maksimal kinerjanya dibandingkan dengan para guru yang mendapat motivasi berupa insentif atau bentuk lainnya.

Dengan disiplin dapat mendorong gairah yang kerja, semangat kerja sehingga tujuan yang telah direncanakan dapat tercapai. Karena kedisiplinan bagi guru tidak dapat dipisahkan dalam melaksanakan tugas dan kewajiban.

\section{TINJAUAN PUSTAKA}

Mangkunegara (2008) menyatakan bahwa Kinerja adalah hasil kerja secara mutu dan kualitas yang dicapai oleh seorang karyawan dalam melaksanakan tugasnya sesuai dengan tanggung jawab yang diberikan kepadanya.

Mangkunegara (2008), mendefinisikan kinerja karyawan sebagai prestasi kerja atau hasil kerja baik kualitas maupun kuantitas yang dicapai oleh karyawan per satuan periode waktu dalam melaksanakan tugas kerjanya sesuai dengan tanggung jawab yang diberikan

kepadanya. Menurut Sedarmayanti (2007), kinerja merupakan hasil kerja seorang pekerja di dalam sebuah proses 
Jurnal Ilmiah Ekonomi dan Bisnis

Vol. 15. No. 2, September 2018: 150-164

EISSN : $2442-9813$

ISSN : $1829-9822$

manajemen atau suatu organisasi secara keseluruhan dimana hasil kerja tersebut dapat ditunjukkan buktinya secara kongkrit dan dapat diukur (dibandingkan dengan standar yang telah ditentukan). Sementara menurut Wirawan (2009), kinerja merupakan keluaran yang dihasilkan oleh fungsi-fungsi atau indikator-indikator suatu pekerjaan atau suatu profesi dalam waktu tertentu.

Kinerja karyawan merupakan suatu hasil kerja yang di capai seseorang dalam melaksanakan tugas-tugas diberikan kepadanya yang didasarkan atas kecakapan pengalaman dan kesungguhan serta waktu (Hasibuan, 2010). Kinerja merupakan hasil pekerjaan yang mempunyai hubungan kuat dengan tujuan strategis organisasi, kepuasan konsumen, dan memberikan kontribusi pada ekonomi (Wibowo, 2007). Berdasarkan uraian tersebut di atas dengan pencatatan hasil kerja (proses) yang dicapai oleh seseorang karyawan dalam melakukan suatu pekerjaan dapat dievaluasi tingkat kinerja pegawainya, maka kinerja karyawan harus dapat ditentukan dengan pencapaian target selama periode waktu yang dicapai organisasi.

Menurut Guritno dan Waridin (2005), "Kinerja merupakan perbandingan hasil kerja yang dicapai oleh karyawan dengan standar yang telah ditentukan." Selanjutnya kinerja adalah sebagai hasil kerja yang dicapai oleh individu yang disesuaikan dengan peran atau tugas individu didalam suatu perusahaan pada suatu periode waktu tertentu, yang dihubungkan dengan suatu ukuran nilai atau standar tertentu dari perusahaan tempat individu tersebut bekerja. Menurut Rivai dan Basri (2005), "Kinerja adalah kesediaan seseorang atau kelompok orang untuk melakukan sesuatu kegiatan dan menyempurnakannya sesuai dengan tanggung jawab dengan hasil seperti yang diharapkan." Menurut Hersey dan
Blanchard (2000), "Kinerja sebagai hasilhasil yang telah dicapai seseorang dengan menggunakan media tertentu. Batasan ini menggambarkan bahwa kinerja seseorang tidak terlepas dari media yang digunakan individu tersebut." Dengan penggunaan media yang tepat, maka kinerja individu tersebut akan menjadi lebih baik.

Menurut As'ad (2003) kinerja merupakan kesuksesan seseorang di dalam melaksanakan suatu pekerjaan. Dari batasan tersebut, As'ad menyimpulkan bahwa kinerja adalah suatu hasil yang dicapai seseorang menurut ukuran yang berlaku untuk pekerjaan yang bersangkutan. Meningkatnya kinerja perorangan (individual performance) maka kemungkinan besar juga akan meningkatkan kinerja perusahaan (coorporate performance) karena keduanya mempunyai hubungan yang erat. Menurut Mangkuprawira dan Hubeis (2007) kinerja adalah hasil proses pekerjaan tertentu secara terencana pada waktu dan tempat dari pegawai serta organisasi bersangkutan. Ukuran kinerja dapat dilihat dari sisi jumlah dan mutu tertentu sesuai.

dengan standar organisasi atau perusahaan. Menurut Sedarmayanti (2011) kinerja adalah hasil yang dapat dicapai oleh seseorang atau sekelompok orang dalam suatu organisasi, sesuai dengan wewenang dan tanggung jawab masing-masing, dalam rangka upaya mencapai tujuan organisasi bersangkutan secara ilegal, tidak melanggar hukum sesuai dengan moral maupun etika. Kinerja pegawai merupakan hasil kerja secara kualitas dan kuantitas yang dicapai oleh pegawai dalam melaksanakan tugasnya sesuai dengan tanggung jawab yang diberikan kepadanya. Kinerja pegawai akan tercapai apabila didukung faktor-faktor yang mempengaruhi kinerja. 
Menurut Timple (2000) dalam Siti Munafiah (2011) terdapat dua faktor yang mempengaruhi Kinerja Karyawan yaitu faktor internal dan faktor eksternal. Faktor internal adalah faktor-faktor yang berhubungan dengan sifat-sifat seseorang meliputi sikap, sifat kepribadian, sifat fisik, motivasi, umur, jenis kelamin, pendidikan, pengalaman kinerja, latar belakang budaya, dan variabel personal lainnya. Faktor eksternal adalah faktor-faktor yang mempengaruhi kinerja karyawan yang berasal dari lingkungan meliputi kebijakan organisasi, kepemimpinan, tindakan -tindakan rekan kerja, pengawasan, sistem upah, dan lingkungan sosial. c. Dimensi dan Indikator Kinerja Karyawan "Menurut Richard I. Handerson (1984) dalam Wirawan (2009) dimensi kinerja adalah kualitas- kualitas atau wajah suatu pekerjaan atau aktivitas- aktivas yang terjadi di tempat kerja yang konduktif terhadap pengukuran". Dimensi kinerja menyediakan alat untuk melukiskan keseluruhan cakupan aktivitas di tempat kerja. Sementara itu, tanggung jawab dan kewajiban menyediakan suatu deskripsi depersonalisasi.

Menurut Wirawan (2009)

dimensi kinerja dikelompokkan menjadi tiga jenis yaitu hasil kerja, perilaku kerja, dan sifat pribadi yang berhubungan dengan pekerjaan. Indikator- indikator kinerja karyawan menurut Chester I. Barnard dan Robert E. Quinn dalam Suyadi Prawirosentono (2008) adalah sebagai berikut: 1) Efektivitas dan efisiensi Bila suatu tujuan tertentu akhirnya dapat dicapai, kita boleh mengatakan bahwa kegiatan tersebut efektif. Apabila akibat-akibat yang dicari dari kegiatan mempunyai nilai yang lebih penting dibandingkan hasil yang tercapai, sehingga mengakibatkan ketidakpuasan walaupun efektif, hal ini disebut tidak efisien. Sebaliknya jika akibat yang tidak dicari- cari tidak penting/remeh, maka kegiatan tersebut efisien. Sehubungan dengan itu kita dapat mengatakan sesuatu efektif bila mencapai tujuan tertentu. Dikatakan efisien bila hal itu memuaskan sebagai pendorong mencapai tujuan, terlepas apakah efektif atau tidak. 2) Otoritas dan tanggung jawab Wewenang adalah hak seseorang untuk memberikan perintah (kepada bawahan), sedangkan tanggung jawab adalah bagian yang tidak terpisahkan atau sebagai akibat dari kepemilikan wewenang tersebut. Bila ada wewenang berarti dengan sendirinya muncul tanggung jawab. 3) Disiplin Disiplin meliputi ketaatan dan hormat terhadap perjanjian yang dibuat antara perusahaan dan karyawan. Disiplin juga berkaitan erat dengan sanksi yang perlu dijatuhkan kepada pihak yang melanggar. 4) Inisiatif Inisiatif seseorang berkaitan dengan daya pikir, kreativitas dalam bentuk ide untuk merencanakan sesuatu yang berkaitan dengan tujuan organisasi.

Motivasi kerja menurut Gibson et al. (1997) adalah kekuatan yang mendorong seorang karyawan yang menimbulkan dan mengarahkan perilaku. Motivasi merupakan hasrat di dalam seseorang yang menyebabkan orang tersebut melakukan tindakan. Wahyusumidjo (1987) menyatakan bahwa moti-vasi merupakan daya dorong sebagai hasil proses interaksi antara sikap, kebutuhan, dan persepsi bawahan dari seseorang dengan lingkungan, motivasi timbul diakibatkan oleh faktor dari dalam dirinya sendiri disebut faktor instrinsik, dan faktor yang dari luar diri seseorang disebut faktor ekstrinsik.

Mc Clelland et al. (1953) mengambil teori asalnya dengan konsep motif prestasi yang dikemukakan oleh Murray pada tahun 1938. Teori ini penekanannya pada keperluan peringkat tinggi, yang menyatakan bahwa individu yang tinggi motivasi berprestasi akan menunjukkan keutamaan yang tinggi kepada situasi yang sederhana, yaitu 
Jurnal Ilmiah Ekonomi dan Bisnis

Vol. 15. No. 2, September 2018: 150-164

EISSN : $2442-9813$

ISSN : $1829-9822$

kemungkinan derajat mencapai keberhasilan dan kegagalan adalah sama. Sebaliknya orang-orang yang rendah motivasi berprestasinya suka kepada situasi yang sangat sukar atau sangat mudah mencapai keberhasilan (Atkinson \& Birch, 1978; Mc Clelland, 1961).

McClelland (1961) memberi ciriciri yang ada pada individu yang mempunyai motivasi berprestasi/ pencapaian yang tinggi, yaitu: a) suka membuat kerja yang berkaitan dengan prestasi, b) suka mengambil risiko yang sederhana, c) lebih suka membuat kerja yang mana individu itu bertanggungjawab bagi keberhasilan kerja itu, d) suka rnendapat kemudahan tentang kerja itu, e) lebih mementingkan masa depan daripada masa sekarang dan masa yang telah lalu, dan f) tabah apabila menemui kegagalan. Sifat-sifat tersebut dikatakan sebagai puncak yang membedakan seseorang. Seorang individu lebih berhasil daripada individu yang lain karena mereka mempunyai keinginan pencapaian yang lebih tinggi. Keinginan ini memberi mereka motivasi untuk bekerja dengan lebih tekun (McClelland et al., 1953).

Selanjutnya, Mc Clelland (1961) menyatakan bahwa motivasi berprestasi/pencapaian bukan sesuatu yang diwariskan. Disebabkan pengaruh situasi di-sekitarnya, maka motivasi berprestasi/pencapaian boleh dibentuk mengikut cara tertentu. Davis \& Newstroom (1985) mendefinisikan motivasi ber-prestasi (achievement motivation) adalah dorongan dalam diri orang-orang untuk mengatasi segala tantangan dan hambatan dalam upaya mencapai tujuan. Penelitian yang dilakukan Hernowo dan Farid menunjukkan bahwa terdapat pengaruh yang signifikan dan positif antara variabel motivasi ter-hadap kinerja pegawai BKD Kabupaten Wonogiri.

(Susanty \& Baskoro, 2012) Motivasi mempersoalkan bagaimana cara mengarahkan daya dan potensi yang dimiliki oleh bawahan sehingga bawahan mau bekerja sama secara produktif untuk mencapai dan mewujudkan tujuan yang telah ditentukan. Motivasi merupakan hal yang penting karena motivasi dapat menjadi penyebab, penyalur, maupun pendukung dari perilaku seseorang sehingga orang tersebut berkeinginan untuk bekerja keras dan antusias untuk mencapai hasil yang optimal. Menurut Terry dan Rue dalam Suharto dan Budi Cahyono (2005), motivasi adalah "getting a person to exert a high degree of effort" yang artinya adalah "motivasi membuat seseorang dapat bekerja lebih kerja". Sejalan dengan hal tersebut, Luthans (2006) menyatakan bahwa motivasi adalah sebuah suatu dorongan yang ditunjukan untuk memenuhi tujuan tertentu.

Atiomo (2000) dalam Adomi dan Eruvwe (2004), mendefinisikan disiplin sebagai pelatihan pikiran dan karakter untuk menghasilkan pengendalian diri dan kebiasaan untuk patuh. Rivai (2004) Disiplin kerja adalah suatu alat yang digunakan para manajer untuk berkomunikasi dengan karyawan agar mereka bersedia untuk mengubah suatu perilaku serta sebagai suatu upaya untuk meningkatkan kesadaran dan kesediaan seseorang menaati semua peraturan perusahaan dan norma-norma sosial yang berlaku.

Heidjrachman dan Husnan (2000) dalam Sinambela (2012), disiplin adalah setiap perseorangan atau kelompok yang yang menjamin adanya kepatuhan terhadap "perintah" dan berinisiatif untuk melakukan suatu tindakan yang diperlukan seandainya tidak ada "perintah". (Hasibuan, 2008) disiplin adalah kesadaran dan kesediaan seseorang mentaati semua peraturan perusahaan dan norma-norma sosial yang berlaku.

Mangkunegara (2001) dalam Sinambela (2012) terdapat dua indikstor disiplin kerja, yaitu disiplin preventif dan 
disiplin korektif. Hasibuan (2008) menjelaskan indikator kedisiplinan karyawan suatu organisasi, yaitu tujuan dan kemampuan, teladan pimpinan, balas jasa, keadilan, pengawasan melekat, sanksi hukuman, ketegasan, dan hubungan kemanusiaan.

Sutrisno (2011) mengatakan bahwa disiplin adalah sikap kesediaan dan kerelaan seseorang untuk mematuhi dan mentaati norma-norma peraturan yang berlaku di sekitarnya, dan disiplin karyawan yang baik akan mempercepat pencapaian tujuan perusahaan, sedangkan disiplin yang merosot akan menjadi penghalang dan memperlambat pencapaian tujuan perusahaan. Saputra (2007), Mutmainnah (2008), dan Harlie (2010), dalam penelitiannya menemukan bahwa terdapat hubungan positif antara disiplin kerja dengan kinerja.

Disiplin kerja merupakan suatu sikap menghormati, menghargai, patuh, dan taat terhadap peraturan-peraturan yang berlaku, baik yang tertulis maupun yang tidak tertulis serta sanggup menjalankannya dan tidak mengelak untuk menerima sanksi-sanksinya (Ardana, 2012). Disiplin kerja dapat diartikan sebagai bentuk sikap, mental, pengetahuan dan perilaku pegawai untuk secara sukarela berusaha secara kooperatif dengan pegawai lain, menaati ketentuan-ketentuan dan standar kerja yang berlaku, serta berusaha meningkatkan kinerjanya (Siagian, 2007), dapat disimpulkan bahwa disiplin kerja pegawai merupakan sikap atau tingkah laku yang menunjukkan kesetiaan dan ketaatan seseorang atau sekelompok orang terhadap peraturan yang telah ditetapkan oleh instansi atau organisasinya baik yang tertulis maupun tidak tertulis sehingga diharapkan pekerjaan yang dilakukan efektif dan efesien.

Handoko (2001) mendefinisikan, "Disiplin adalah kegiatan manajemen untuk menjalankan standar-standar organisasi." Selanjutnya Handoko membedakan disiplin kedalam tiga jenis, yaitu disiplin preventif, korekti,f dan progresif. (1) Disiplin Preventif, yaitu disiplin yang dilakukan untuk mendorong para pegawai agar mengikuti berbagai standar dan aturan, sehingga penyelewengan dapat dicegah. Tujuan disiplin adalah untuk mendorong timbulnya disiplin diri mereka bukan semata-mata dipaksakan manajemen. (2) Disiplin Korektif, yaitu untuk menangani pelanggaran-pelanggaran lebih lanjut. Kegiatan korektif sering berupa suatu bentuk hukuman dan disebut tindakan pendisiplinan (diciplinary action) berupa peringatan skorsing. Sasaran bersifat positif yaitu mendidik dan mengoreksi, bukan tindakan negatif untuk menghancurkan pegawai yang sudah salah., dan (3) Disiplin Progresif, yaitu memberikan hukuman yang lebih berat terhadap pelanggaran berulang. Tujuannya adalah untuk memberikan kesempatan kepada karyawan agar mengambil tindakan korektif sebelum hukuman yang serius dijatuhkan. Disiplin progresif juga memungkinkan manajemen untuk membantu pegawai memperbaiki kesalahan.

Manullang (2000) menyatakan, "Disiplin adalah salah satu keadaan tingkah laku manusia, sikap dan kelakuan yang diatur dengan peraturan yang berlaku serta sanksi yang dikeluarkan." Sementara Hasibuan (2001) memberikan pengertian, "Kedisiplinan adalah kesadaran dan kesediaan seseorang menerima semua aturan perusahaan dan norma-norma sosial yang berlaku." Siagian (2002) mengemukakan, "Disiplin merupakan tindakan manajemen untuk mendorong para anggota organisasi memenuhi tuntutan berbagai ketentuan."

Menurut Simamora (1997), disiplin adalah prosedur yang mengoreksi atau menghukum bawahan karena melanggar peraturan atau prosedur. Disiplin kerja adalah suatu alat yang 
Jurnal Ilmiah Ekonomi dan Bísnis

Vol. 15. No. 2, September 2018: 150-164

EISSN : $2442-9813$

ISSN : $1829-9822$

digunakan para manajer untuk berkomunikasi dengan karyawan agar mereka bersedia untuk mengubah suatu perilaku serta sebagai suatu upaya untuk meningkatkan kesadaran dan kesediaan seseorang menaati semua peraturan perusahaan dan norma-norma sosial yang berlaku (Rivai, 2004). Hasibuan (2004) berpendapat bahwa kedisiplinan adalah kesadaran dan kesediaan seseorang menaati semua peraturan perusahaan dan norma-norma social yang berlaku. Berdasarkan pengertian diatas disimpulkan bahwa disiplin kerja merupakan suatu sikap, tingkah laku, dan perbuatan yang sesuai dengan peraturan baik tertulis maupun tidak tertulis, dan bila melanggar akan ada sanksi atas pelanggarannya.

\section{METODE PENELITIAN}

Penelitian ini menggunakan pendekatan kuantitatif dimana analisis data bersifat kuantitatif untuk menguji hipotesis yang telah dirumuskan. Dilihat dari tingkat eksplanasinya penelitian ini bersifat asosiatif, dimana dalam penelitian ini dikaji hubungan antar beberapa konsep atau variabel.

Teknik analisis data yang digunakan dalam penelitian ini adalah sebagai berikut :

Uji Validitas

Valiliditas dilakukan berkenaan dengan ketepatan alat ukur terhadap konsep yang hendak diukur sehingga benar-benar mengukur apa yang seharusnya diukur. Dengan rumus:

$$
=\frac{r_{\text {hitung }}}{\sqrt{\left\{n \cdot \sum X_{i}^{2}-\left(\sum X_{i} Y_{i}\right)-\left(\sum X_{i}\right) \cdot\left(\sum Y_{i}\right)\right.}}
$$

Di mana $: r$ hitung $=$ Koefisien korelasi

$\Sigma \mathrm{Xi}=$ Jumlah skor item

$\Sigma \mathrm{Yi}=$ Jumlah skor total (seluruh item)

$\mathrm{n}=$ Jumlah responden
Dengan ketentuan:

Apabila nilai $r$ hitung lebih besar dari nilai $r$ tabel ( $r$ hitung $>r$ tabel), maka data dianggap valid. Sebaliknya, apabila nilai $r$ hitung lebih kecil dari nilai $r$ tabel maka data dikatakan tidak valid.

Dimana:

$\mathrm{n}=$ Sampel

$\mathrm{k}=$ Jumlah Variabel

$\mathrm{df}=$ nilai $\mathrm{r}$ table

\section{Uji Reliabilitas}

Pengujian reliabilitas digunakan untuk mengukur konsistensi jawaban responden, kriteria pengujian dilakukan dengan menggunakan pengujian Cronbach Alpha. Kriteria penggunaan cronbach alpha dengan menggunakan rumus sebagai berikut :

$\mathrm{r}_{11}=\left[\frac{\mathrm{K}}{\mathrm{K}-1}\right]\left[-\frac{\sum \mathrm{S}_{\mathrm{i}}}{\mathrm{S}_{\mathrm{t}}}\right]$

Di mana : r11 = Nilai reabilitas

$\Sigma \mathrm{Si}=$ Jumlah varians skor tiap-tiap item

$\mathrm{St}=$ Varians total

$\mathrm{k}=$ Jumlah item

Dimana suatu variabel dikatakan realibel apabila nilai koefisien alpha yang diperoleh lebih besar 0,6 (> 0,6), sebaliknya variabel dikatakan tidak realibel jika nilai koefisien alpha lebih kecil dari 0,6 $(<0,6)$. Setelah kusioner diuji validitas dan realibilitasnya dan ternyata valid dan realibel baru kusioner bisa disebarkan kepada responden. Setelah kusioner disebarkan dan hasil kusioner tersebut akan diolah menggunakan program Komputer SPSS (Statistic for Sosial Science) (Ghozali, 2012).

Uji normalitas bertujuan untuk menguji apakah dalam model regresi, variabel penganggu atau residual memiliki distribusi normal (Ghozali, 2012). Cara termudah untuk melihat normalitas residual adalah dengan melihat grafik histogram yag membandingkan antara data observasi dengan distribusi yang mendekati distribusi normal. Distribusi normal akan membentuk satu 
garis diagonal. Dan ploting data residual akan dibandingkan dengan garis diagonal. Jika distribusi data residual normal, maka garis yang menggambarkan data sesungguhnya akan mengikuti garis diagonalnya (Ghozali, 2012).

Uji Linearitas

Uji linieritas digunakan untuk mengetahui hubungan antara variabel bebas dan variabel terikat

bersifat linier atau tidak. (Hadi, 2004) Kriteria yang digunakan yaitu regresi dikatakan linier jika Fhitung < Ftabel, selain itu data dapat dikatakan linier jika nilai signifikansi lebih besar dari alpha yang ditentukan yaitu 5\% (Ghozali, 2012).

\section{Uji Multikolinearitas}

Uji multikolinieritas bertujuan untuk menguji apakah dalam model regresi ditemukan adanya korelasi antar variabel bebas (independen). Untuk mendeteksi ada atau tidaknya multikolinearitas maka dilakukan dengan melihat nilai Tolerance Value dan Variance Inflation Factor (VIF). Tolerance Value mengukur variabilitas variabel independen yang terpilih yang tidak dijelaskan oleh variabel independen lainnya. Jadi, nilai tolerance yang rendah sama dengan nilai VIF tinggi karena VIF $=1$ /Tolerance Value) Nilai yang umum dipakai untuk menunjukkan adanya mulitkolonieritas adalah nilai Tolerance Value $<0,01$ atau sama dengan nilai VIF > 10 maka tidak terjadi multikolineritas antara variabel independennya (Ghozali, 2012).

\section{Uji Heteroskedatisitas}

Uji Heteroskedastisitas bertujuan untuk menguji apakah dalam model regresi terjadi ketidaksamaan variance dari residual satu pengamatan ke pengamatan yang lain. Jika variance dari residual satu pengamatan ke pengamatan lain tetap maka disebut homokedastisitas dan jika berbeda disebut heteroskedastisitas.

heteroskedastisitas menggunakan metode uji glejser yang mengusulkan untuk meregres nilai absolut residual terhadap variabel independen. Jika variabel independen secara signifikan secara statistik tidak mempengaruhi variabel dependen, maka tidak terdapat indikasi terjadi heteroskedastisitas. Hal ini dapat dilihat apabila dari probabilitas signifikansinya di atas tingkat kepercayaan 5\% (Ghozali, 2012).

Analisis Regresi Linear Berganda

Analisis Regresi Linear Berganda Analisis regresi berganda digunakan untuk memprediksi pengaruh dua variabel bebas atau lebih terdapat satu variabel terikat. Lngkah-langkah dalam analisis regresi berganda adalah sebagai berikut:

Membuat persamaan garis regresi dua prediktor dengan rumus sebagai berikut:

$\mathrm{Y}=\mathrm{a}+\mathrm{b}_{1} \mathrm{X}_{1}+\mathrm{b}_{2} \mathrm{X}_{2}+\mathrm{e}$ dimana:

$$
\mathrm{Y}=\text { Variabel dependen }
$$

(Kinerja Guru)

$$
\begin{array}{lrr}
\mathrm{a} & =\text { Konstanta } \\
\mathrm{b}_{1}, \mathrm{~b}_{2} & =\text { Koefisien regresi } \\
\mathrm{X}_{1} & =\text { Motivasi kerja } \\
\mathrm{X}_{2} & = & \text { Disiplin kerja } \\
\mathrm{e} & = & \text { Kesalahan }
\end{array}
$$

prediksi (error term)

Untuk mendapatkan nilai parameter a dan b digunakan pendekatan metode Olldinery Last Squere (OLS) dengan menggunakan program SPSS 20.00.

Koefisien Determinasi $\left(\mathrm{R}^{2}\right)$

Mencari kofisien determinasi (r2)

antara prediktor $\mathrm{X} 1$ dengan $\mathrm{Y}$ dan prediktor X2 dengan $\mathrm{Y}$.

rumusnya:

$$
R^{2}=\frac{\left\{n \sum x y-\left(\sum x\right)\left(\sum y\right)\right\}^{2}}{\left\{n \sum x^{2}-\left(n \sum x^{2}\right)\right\}\left\{n \sum y^{2}-\left(\sum y\right)^{2}\right\}}
$$


Jurnal Ilmiah Ekonomi dan Bísnis

Vol. 15. No. 2, September 2018: 150-164

EISSN : $2442-9813$

ISSN : $1829-9822$

Besarnya R2 dihitung dengan membagi jumlah Yestimasi dikurangirata-rata kwadrat (sum square) dengan jumlah $\mathrm{Y}$ terobsesi dikurangi Yrata-rata kwadarat. Nilai R2 adalah antara 0 sampai dengan 1, bila R2mendekati 1 maka model yang dipilih mendekati kebenaran. (Sutrisno Hadi, 2004).

Uji T

Menguji signifikansi dengan uji t Menguji koefisien garis regresi digunakan uji statistik t. Uji t dilakukan untuk menguji signifikansi konstanta tiap variabel independen akan berpengaruh terhadap variabel dependen dengan (Sugiyono,2009) rumus:

$$
t_{0}=\frac{b_{i}}{s b_{i}}
$$

Keterangan:

$\mathrm{t}_{0} \quad=$ Nilai $\mathrm{t}_{\text {hitung }}$

$\mathrm{b}_{\mathrm{i}} \quad=$ Koefisien regresi

$\mathrm{sb}_{\mathrm{i}}=$ Standar Deviasi atas koefisien regresi $\mathrm{X}_{\mathrm{i}}$

Uji statistik t pada dasarnya menunjukan seberapa jauh pengaruh variabel independen secara individual dalam mnerangkan variasi variabel dependen. Dalam mengambil keputusan dilakukan dengan membandingkan nilai antara thitung dan ttabel dengan taraf sinifikansi 5\%. Apabila nilai statistik $\mathrm{t}$ lebih tinggi dibandingkan nilai ttabel, maka variabel independen secara individual memiliki pengaruh yang signifikan terhadap variabel dependen (Ghozali, 2012).

Uji F

Untuk menguji apakah variabel motivasi kerja (X1), dan disiplin kerja (X2) secara bersama-sama (simultan) berpengaruh terhadap Kinerja guru (Y), maka digunakan uji $\mathrm{F}$.

$$
F \text { hitung }=\frac{R^{2} / k}{\left(1-R^{2}\right) /(n-k-1)}
$$

Keterangan:

$$
\begin{aligned}
\mathrm{R}^{2} & =\text { Koefisien determinasi } \\
\mathrm{k} & =\text { Banyaknya variabel } \\
& \text { bebas } \\
\mathrm{n} & =\text { jumlah data }
\end{aligned}
$$

\section{HASIL DAN PEMBAHASAN}

Uji validitas dilakukan dengan menggunakan 48 sampel guru yang diolah dengan menggunakan SPSS 20.00 untuk menentukan valid atau tidaknya suatu item ditentukan oleh $r$ hitung yang harus besar dari 0,2732 sebagai $r$ tabel dan tidak mengalami keraguan, maksudnya suatu item harus menghasilkan faktor loading yang besar dari 0,2732. Item yang tidak valid maka akan dikeluarkan dalam penelitian ini. Dalam penelitian ini yang menggunakan satu variable terikat yaitu kinerja guru dan dua variable bebas yaitu motivasi keja dan disiplin kerja. Pada masing-masing variable di atas berdasarkan tabel dapat kita uji validitas untuk masing-masing instrumen setiap variabel apakah setiap pernyataan valid. Hasil dari uji validitas terhadap masing-masing pernyataan dapat dilihat pada tabel 1. di bawah ini :

Tabel 1. Hasil Uji Validitas Variable Motivasi Kerja (X1)

\begin{tabular}{|l|l|l|l|}
\hline Item & r tabel & r hitung & $\begin{array}{l}\text { Keter } \\
\text { angan }\end{array}$ \\
\hline Motivasi1 & 0,273 & 0.503 & Valid \\
\hline Motivasi2 & 0,273 & 0.708 & Valid \\
\hline Motivasi3 & 0,273 & 0.424 & Valid \\
\hline Motivasi4 & 0,273 & 0.784 & Valid \\
\hline Motivasi5 & 0,273 & 0.674 & Valid \\
\hline Motivasi6 & 0,273 & 0.424 & Valid \\
\hline
\end{tabular}

Sumber : Hasil Pengolahan data Primer Tahun 2018

Berdasarkan tabel 1. di atas menunjukkan hasil dari uji validitas yang menunjukkan bahwa seluruh item pertanyaan pada kuesioner motivasi kerja dapat digunakan untuk mewakili pernyataan pada tiap variable dari motivasi kerja tersebut. Hal ini terbukti dari nilai cronbach alpha yang diperoleh lebih besar dari 0,2732 dan tidak ada yang mengalami kerancuan. Jadi dapat disimpulkan bahwa dari lima pernyataan untuk mengukur motivasi kerja guru di Sekolah Menengah Atas Negeri 11 Sijunjung dapat digunakan untuk 
melakukan pengujian selanjutnya.

Hasil uji validitas untuk variable Disiplin kerja guru Sekolah Menengah Atas Negeri 11 Sijunjung dapat dilihat pada tabel 2. di bawah ini :

Tabel 2. Hasil Uji Validitas Variable Disiplin Kerja (X2)

\begin{tabular}{|l|l|l|l|}
\hline Item & $\begin{array}{l}\text { r } \\
\text { tabel }\end{array}$ & r hitung & $\begin{array}{l}\text { Keterang } \\
\text { an }\end{array}$ \\
\hline Disiplin 1 & 0,273 & 0.565 & Valid \\
\hline Disiplin 2 & 0,273 & 0.829 & Valid \\
\hline Disiplin 3 & 0,273 & 0.497 & Valid \\
\hline Disiplin 4 & 0,273 & 0.360 & Valid \\
\hline Disiplin 5 & 0,273 & 0.333 & Valid \\
\hline Disiplin 6 & 0,273 & 0.331 & Valid \\
\hline Disiplin 7 & 0,273 & 0.420 & Valid \\
\hline Disiplin 8 & 0,273 & 0.403 & Valid \\
\hline
\end{tabular}

Sumber : Hasil Pengolahan data Primer Tahun 2018

Berdasarkan tabel 2. di atas menunjukkan hasil dari uji validitas yang menunjukkan bahwa seluruh item pertanyaan pada kuesioner disiplin kerja tersebut dapat digunakan untuk mewakili pernyataan pada tiap variable disiplin kerja guru di Sekolah Menengah Atas Negeri 11 Sijunjung. Hal ini terbukti dari nilai cronbach alpha yang diperoleh lebih besar dari 0,273 dan tidak ada yang mengalami kerancuan.

Selanjutnya hasil uji validitas data untuk variable kinerja guru dapat dilihat pada tabel 3. di bawah ini ;

Tabel 3. Hasil Uji Validitas Variable Kinerja Guru (Y)

\begin{tabular}{|c|c|c|c|}
\hline Item & $\mathrm{r}$ tabel & r hitung & $\begin{array}{l}\text { Keterang } \\
\text { an }\end{array}$ \\
\hline Kinerja1 & 0,273 & 0.505 & Valid \\
\hline Kinerja2 & 0,273 & 0.552 & Valid \\
\hline Kinerja3 & 0,273 & 0.802 & Valid \\
\hline Kinerja4 & 0,273 & 0.533 & Valid \\
\hline Kinerja5 & 0,273 & 0.552 & Valid \\
\hline Kinerja6 & 0,273 & 0.604 & Valid \\
\hline Kinerja7 & 0,273 & 0.482 & Valid \\
\hline Kinerja8 & 0,273 & 0.439 & Valid \\
\hline
\end{tabular}

Berdasarkan tabel 3 di atas menunjukkan hasil dari uji validitas yang menunjukkan bahwa seluruh item pertanyaan pada kuesioner kinerja guru tersebut dapat digunakan untuk mewakili pernyataan pada tiap variable kinerja guru di Sekolah Menengah Atas Negeri 11 Sijunjung. Hal ini terbukti dari nilai cronbach alpha yang diperoleh lebih besar dari 0,273 dan tidak ada yang mengalami kerancuan. Jadi dapat disimpulkan bahwa dari delapan item pernyataan dapat digunakan untuk melakukan pengujian selanjutnya.

Uji reliabilitas merupakan alat untuk mengukur suatu kuesioner yang merupakan indikator dari variabel atau konstruk Ghozali, (2012). Uji reliabilitas diukur dengan menggunakan cronbach's alpha $(\alpha)$ dimana hasil yang menunjukkan di atas 0,60 dapat dikatakan reliabel. Hasil perhitungan uji reliabilitas terhadap kuesioner dapat dilakukan dengan menggunakan SPSS 20.00 for windows dapat dilihat pada tabel 5. di bawah ini :

Tabel 4. Hasil Uji Reliabilitas Variabel Penelitian

\begin{tabular}{|l|l|l|l|l|}
\hline No & Variabel & $\begin{array}{l}\text { Alpha } \\
\text { Cron } \\
\text { bach }\end{array}$ & $\begin{array}{l}\text { Alph } \\
\text { a }\end{array}$ & $\begin{array}{l}\text { Ketera } \\
\text { ngan }\end{array}$ \\
\hline 1 & $\begin{array}{l}\text { Kinerja } \\
\text { guru (Y) }\end{array}$ & 0,825 & 0,60 & $\begin{array}{l}\text { Sangat } \\
\text { Reliab } \\
\text { el }\end{array}$ \\
\hline 3 & $\begin{array}{l}\text { Motivasi } \\
\text { kerja } \\
\text { (X1) }\end{array}$ & 0,818 & 0,60 & $\begin{array}{l}\text { Sangat } \\
\text { Reliab } \\
\text { el }\end{array}$ \\
\hline 4 & $\begin{array}{l}\text { Disiplin } \\
\text { kerja } \\
\text { (X2) }\end{array}$ & 0,696 & 0,60 & $\begin{array}{l}\text { Reliab } \\
\text { el }\end{array}$ \\
\hline
\end{tabular}

Sumber : Hasil Pengolahan data Primer Tahun 2018

Berdasarkan Tabel 4. hasil pengolahan data untuk uji reliabilitas variabel penelitian sebagaimana yang terlihat pada tabel di atas terlihat bahwa semua variabel memiliki angka alpha cronbach lebih besar dari 0,6. Hal ini menandakan bahwa semua variabel 
Jurnal Ilmiah Ekonomi dan Bísnis

Vol. 15. No. 2, September 2018: 150-164

EISSN : $2442-9813$

ISSN : $1829-9822$

penelitian memiliki kuesioner yang handal atau reliabel. Dengan demikian dapat disimpulkan bahwa kuesioner yang digunakan untuk mengumpulkan data penelitian sangat handal.

\section{Uji Asumsi Klasik}

Uji Normalitas

$$
\text { Untuk melihat tingkat }
$$

kenormalan suatu data perlu dilakukan uji normalitas dari data tersebut. Pengujian normalitas data dilakukan dengan menggunakan One Sample Kolmogorov Smirnov Test. Ghozali (2012) menyatakan dimana prinsip dari normalitas ditunjukan dengan tingkat signifikansi $5 \%$. Dasar pengambilan keputusan dari uji normalitas ini adalah dengan melihat probabilitas Asymp.Sig (2-tailed). Jika probabilitas Asymp.Sig (2-tiled) $>\alpha$, maka data tersebut berdistribusi normal. Adapun hasil pengolahan data untuk uji normalitas dapat dilihat pada Tabel 5. berikut :

Tabel 5. Uji Normalitas Variabel Penelitian

\begin{tabular}{|l|l|l|l|l|}
\hline No & Variabel & Alpha & $\begin{array}{l}\text { Asy } \\
\text { mp. } \\
\text { Sig }\end{array}$ & $\begin{array}{l}\text { Ketera } \\
\text { ngan }\end{array}$ \\
\hline 1 & $\begin{array}{l}\text { Kinerja } \\
\text { Guru (Y) }\end{array}$ & 0.05 & 0,661 & $\begin{array}{l}\text { Norm } \\
\text { al }\end{array}$ \\
\hline 2 & $\begin{array}{l}\text { Motivasi } \\
\text { kerja } \\
\text { (X1) }\end{array}$ & 0.05 & 0.100 & $\begin{array}{l}\text { Norm } \\
\text { al }\end{array}$ \\
\hline 3 & $\begin{array}{l}\text { Disiplin } \\
\text { kerja } \\
\text { (X2) }\end{array}$ & 0.05 & 0,565 & $\begin{array}{l}\text { Norm } \\
\text { al }\end{array}$ \\
\hline
\end{tabular}

Sumber : Hasil Pengolahan data Primer Tahun 2018

Berdasarkan tabel 5 pengujian normalitas terhadap ketiga variabel, ternyata nilai Asymp.Sig ketiga variabel tersebut lebih besar dari $\alpha=5 \%$. Untuk variabel Kinerja guru nilai Asymp.Sig sebesar 0,661, ini berarti 0,661>0.05. Maka dapat disimpulkan bahwa variabel kinerja guru datanya terdistribusi secara normal. Begitu pula dengan variabel motivasi kerja nilai Asymp.Sig sebesar $(0,100>0.05)$, maka dapat disimpulkan bahwa variabel motivasi kerja datanya terdistribusi secara normal. Untuk variabel disiplin kerja nilai Asymp.Sig sebesar 0,565, ini berarti 0,565>0.05. Maka dapat disimpulkan bahwa variabel disiplin kerja juga berdistribusi secara normal.

Uji Linearitas

Uji linearitas digunakan untuk melihat apakah spesifikasi model yang digunakan sudah benar atau tidak. Untuk menentukan apakah fungsi persamaan regresi yang digunakan berbentuk liner dapat digunakan teknik yang digunakan adalah deviation from linearity. Apabila nilainya linearity diatas dari $5 \%$, maka model regresi dapat dinyatakan linier.

Tabel 6. Hasil Uji Linearitas Variabel Penelitian

\begin{tabular}{|l|l|l|l|l|}
\hline No & Variabel & Alpha & $\begin{array}{l}\text { Asy. } \\
\text { Sign }\end{array}$ & $\begin{array}{l}\text { Keter } \\
\text { angan }\end{array}$ \\
\hline 1 & $\begin{array}{l}\text { Kinerja guru } \\
-\quad \text { Motivasi } \\
\text { kerja }\end{array}$ & 0,05 & 0,730 & $\begin{array}{l}\text { Linea } \\
\mathrm{r}\end{array}$ \\
\hline 2 & $\begin{array}{l}\text { Kinerja guru } \\
-\quad 0,05 \\
\text { kerja }\end{array}$ & 0,554 & $\begin{array}{l}\text { Linea } \\
\mathrm{r}\end{array}$ \\
\hline
\end{tabular}

Sumber : Hasil Pengolahan data Primer Tahun 2018

Berdasarkan tabel 6. terlihat bahwa nilai signifikansi (Sig) dari masingmasing variabel bebas lebih besar dari tingkat signifikannya ( $\alpha=0,05)$. Hal ini berarti terjadi hubungan yang linear dari variabel bebas terhadap variabel terikat.

\section{Uji Multikolinearitas}

Pengujian multikolinearitas dilakukan untuk mengetahui apakah antar variabel bebas memiliki hubungan satu sama lainnya uji ini dilakukan untuk mengetahui apakah terdapat kasus multikolinearitas antara sesama variabel bebas. Hasil uji multikolineritas dapat dilihat pada Tabel 7. di bawah ini. 
Tabel 7. Hasil Uji Multikolinearitas

\begin{tabular}{|c|c|c|c|c|}
\hline \multirow{2}{*}{$\mathrm{Nc}$} & \multirow{2}{*}{$\begin{array}{l}\text { Variabe } \\
1\end{array}$} & \multicolumn{2}{|c|}{$\begin{array}{l}\text { Collinearity } \\
\text { Statistics }\end{array}$} & \multirow{2}{*}{$\begin{array}{l}\text { Keteran } \\
\text { gan }\end{array}$} \\
\hline & & Tolerance & VIF & \\
\hline 1 & $\begin{array}{l}\text { Motiva } \\
\text { si kerja }\end{array}$ & 0,936 & $\begin{array}{l}1,06 \\
8\end{array}$ & $\begin{array}{l}\text { Tidak } \\
\text { Ada } \\
\text { Multikol } \\
\text { inearitas }\end{array}$ \\
\hline 2 & $\begin{array}{l}\text { Disiplin } \\
\text { kerja }\end{array}$ & 0,936 & $\begin{array}{l}1,06 \\
8\end{array}$ & $\begin{array}{l}\text { Tidak } \\
\text { Ada } \\
\text { Multikol } \\
\text { inearitas }\end{array}$ \\
\hline
\end{tabular}

Sumber : Hasil Pengolahan data Primer Tahun 2018

Berdasarkan hasil olahan data sebagaimana terlihat pada Tabel 7 diketahui bahwa nilai tolerance dari Collinearity Statistics mendekati 1 (satu) dan nilai VIF (Variance Inflation Factor) untuk semua variabel bebas di bawah 10 (sepuluh). Hal ini menunjukkan bahwa tidak terdapat kasus multikolinearitas antara sesama variabel bebas. Oleh karena itu dapat disimpulkan tidak terdapat kasus multikolinearitas antara sesama variabel bebas. Dengan demikian analisis regresi dapat dilakukan karena uji asumsi klasik sudah memenuhi syarat.

\section{Hasil Analisis Regresi Linear Berganda Analisis regresi berganda} digunakan untuk melihat pengaruh motivasi kerja dan disiplin kerja terhadap kinerja guru Sekolah Menengah Atas Negeri 11 Sijunjung dan sekaligus dalam rangka membuktikan hipotesis yang diajukan dalam penelitian. Persamaan regresi linear berganda berguna untuk melihat pengaruh dari masing-masing variabel bebas terhadap variabel terikat dengan menggunakan pendekatan Ordinary Least Square (OLS). Hasil analisa regresi liner berganda dapat dijelaskan pada Tabel 9 . berikut:
Tabel 8. Hasil Analisa Regresi Berganda

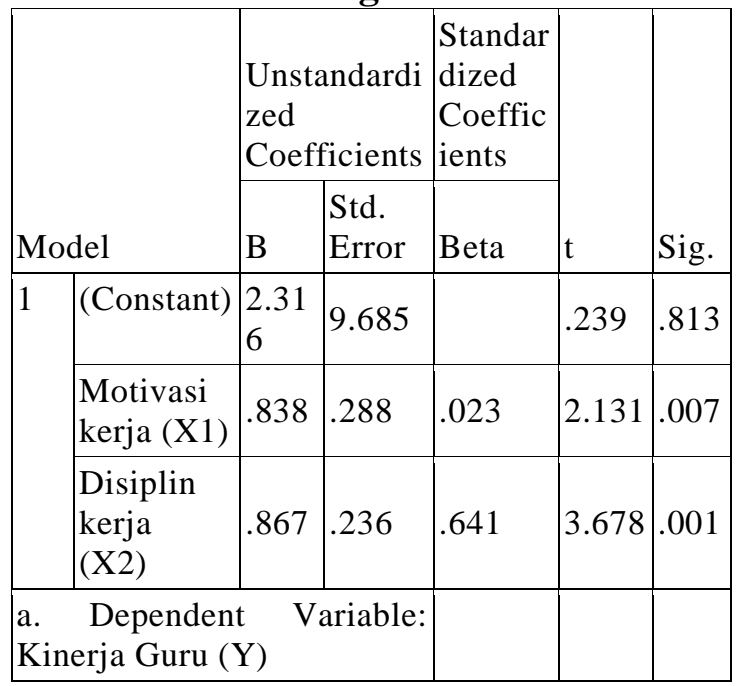

Sumber: Hasil Pengolahan Data Primer, 2018

Kemudian nilai koefisien regresi masing - masing variabel diatas dapat disubtitusikan ke dalam persamaan regresi linear berganda sebagai berikut :

$\mathrm{Y}=2,316+0,838 \mathrm{X} 1+0,867 \quad \mathrm{X} 2$

Dari persamaan tersebut dapat dijelaskan bahwa nilai koefisien regresi untuk masing-masing variabel, nilai konstanta sebesar 2,316 satuan hasil ini menunjukkan bahwa apabila motivasi kerja dan disiplin kerja nilainya nol di Sekolah Menengah Atas Negeri 11 Sijunjung maka kinerja guru adalah sebesar 2,316 satuan.

Kemudian nilai koefisien regresi motivasi kerja (X1) adalah sebesar 0,838 berpengaruh positif terhadap kinerja guru di Sekolah Menengah Atas Negeri 11 Sijunjung, artinya apabila motivasi kerja ditingkatkan sebesar satu satuan di Sekolah Menengah Atas Negeri 11 Sijunjung maka kinerja guru juga akan meningkat sebesar 0,838 satuan dengan asumsi variabel lain tetap.

Kemudian koefisien regresi disiplin kerja (X2) adalah sebesar 0,867 artinya berpengaruh positif terhadap kinerja guru di Sekolah Menengah Atas Negeri 11 Sijunjung, apabila disipin kerja 
Jurnal Ilmiah Ekonomi dan Bísnis

Vol. 15. No. 2, September 2018: 150-164

EISSN : $2442-9813$

ISSN : $1829-9822$

ditingkatkan satu satuan maka kinerja guru di Sekolah Menengah Atas Negeri 11 Sijunjung juga akan meningkat sebeasar 0,867 dengan asumsi variabel lain tetap.

\section{Koefisien Determinan}

Koefisien determinan digunakan untuk melihat kontribusi dari variabel yang penulis teliti secara keseluruhan terhadap variabel terikat, dan dapat dilihat pada tabel 10. dibawah ini :

Tabel 9. Uji Koefisien Determinan Model Summary

\begin{tabular}{|l|l|l|l|l|}
\hline Model & $\mathrm{R}$ & $\begin{array}{l}\mathrm{R} \\
\text { Square }\end{array}$ & $\begin{array}{l}\text { Adjusted } \\
\text { R Square }\end{array}$ & $\begin{array}{l}\text { Std. Error of the } \\
\text { Estimate }\end{array}$ \\
\hline 1 & $.635^{\mathrm{a}}$ & .604 & .547 & 5.86727 \\
\hline
\end{tabular}

a. Predictors: (Constant), Disiplin (X2), Motivasi (X1)

Sumber : Hasil Pengolahan data Primer Tahun 2018

Dari hasil uji Koefisien Determinan diperoleh nilai $\mathrm{R}^{2}$ sebesar 0,604 artinya kontribusi dari variabel motivasi kerja dan disiplin kerja terhadap kinerja guru pada Sekolah Menengah Atas Negeri 11 Sijunjung adalah sebesar $60,4 \%$ artinya motivasi kerja dan disiplin kerja apat dijelaskan sebesar 60,4 \% terhadap kinerja para guru di Sekolah Menengah Atas Negeri 11 Sijunjung sedangkan sisanya 39,6\% lagi dipengaruhi variabel lain yang tidak termasuk dalam penelitian yang penulis lakukan ini.

Pengujian Hipotesis (Uji t)

Berdasarkan perhitungan pada Tabel 10. dibawah ini pengujian hipotesis secara persial. Hasil berikut dapat dijelaskan variabel independen yang di uji dengan uji t secara persial terlihat bahwa variabel tersebut yaitu motivasi kerja (X1) berpengaruh signifikan terhadap kinerja guru pada Sekolah Menengah Atas Negeri 11 Sijunjung, karena nilai signifikansi dari variabel motivasi sebesar 0,007 Dari hasil uji $\mathrm{t}$ pada tabel 10 dibawah ini dapat di jelaskan bahwa :

Tabel 10. Hasil Uji t

\begin{tabular}{|l|l|l|l|l|}
\hline \multicolumn{2}{|l|}{ Model } & $\begin{array}{l}\mathrm{T} \\
\text { hitung }\end{array}$ & T tabel & Sig. \\
\hline 1 & (Constant) & .239 & & .813 \\
\cline { 2 - 5 } & $\begin{array}{l}\text { Motivasi kerja } \\
\text { (X1) }\end{array}$ & 2.131 & 1,962 & .007 \\
\cline { 2 - 5 } & $\begin{array}{l}\text { Disiplin kerja } \\
\text { (X2) }\end{array}$ & 3.678 & 1,962 & .001 \\
\hline
\end{tabular}

Sumber: Hasil Pengolahan Data Primer, 2018

Berdasarkan keterangan artinya lebih kecil dari tingkat signifikansi yang di tetapkan yaitu 0,05 dan juga bisa dilihat dari hasil ujit dengan membandingkan $t$ hitung dengan $t$ tabel dari hasil di atas menunjukkan bahwa $t$ hitung lebih besar dari t tabel $(2,131>$ 1,962) sehingga dapat disimpulkan bahwa hipotesa yang di ajukan dalam penelitian ini dapat diterima dengan tingkat kepercayaan $95 \%$.

Kemudian variabel kedua yaitu disiplin kerja (X2) berpengaruh signifikan terhadap kinerja guru pada Sekolah Menengah Atas Negeri 11 Sijunjung dengan melihat tingkat signifikansi dari variabel disiplin kerja (X2) yaitu sebesar 0,001 artinya lebih kecil dari 0,05 dan jika di lihat dari tabel t hitung dengan $t$ tabel $(3,678>1,962)$ maka dapat disimpulkan bahwa t hitung lebih besar dari t tabel sehingga hipotesa yang di ajukan dapat diterima dengan tingkat kepercayaan $95 \%$.

\section{Uji F}

Untuk menguji pengaruh variabel bebas secara bersama - sama diuji dengan menggunakan uji F. Hasil perhitungan regresi secara bersama - sama diperlihatkan pada Tabel 12. Di bawah ini : 
Jurnal Ilmiah Ekonomi dan Bísnis

Vol. 15. No. 2, September 2018: 150-164 EISSN : $2442-9813$

ISSN : $1829-9822$

Tabel 11. Hasil Uji F Simultan

\begin{tabular}{|l|l|l|l|l|l|l|}
\hline \multicolumn{2}{|l|}{ Model } & $\begin{array}{l}\text { Sum of } \\
\text { Squares }\end{array}$ & df & $\begin{array}{l}\text { Mean } \\
\text { Square }\end{array}$ & F & Sig. \\
\hline \multirow{2}{*}{1} & $\begin{array}{l}\text { Regress } \\
\text { ion }\end{array}$ & 489.077 & 2 & 244.538 & 7.104 & $.004^{\mathrm{a}}$ \\
\cline { 2 - 7 } & $\begin{array}{l}\text { Residua } \\
1\end{array}$ & 722.923 & 21 & 34.425 & & \\
\cline { 2 - 7 } & Total & $\begin{array}{l}1212.00 \\
0\end{array}$ & 23 & & & \\
\hline
\end{tabular}

Sumber : Hasil Pengolahan data Primer Tahun 2018

Dari hasil uji signifikan $\mathrm{F}$ didapat nilai signifikansi 0,004 dan $\mathrm{F}$ hitung 7,104, sedangkan $\mathrm{F}$ tabel sebesar 3,01 jika $\mathrm{F}$ hitung dibandingkan dengan $\mathrm{F}$ tabel maka terbukti bahwa $\mathrm{F}$ hitung lebih besar dari $\mathrm{F}$ tabel $(7,104>3,01)$ ini berarti bahwa model regresi dapat digunakan untuk memprediksi variabel terikat yaitu kinerja guru dan juga bisa dilihat dari tingkat signifikansinya < 0,05 . Dengan demikian, dapat diartikan bahwa variabel motivasi dan disiplin kerja secara bersama - sama berpengaruh signifikan terhadap kinerja guru pada Sekolah Menengah Atas Negeri 11 Sijunjung (Y). Oleh karena itu hipotesis ketiga dalam penelitian ini yang menyatakan bahwa diduga motivasi dan disiplin kerja berpengaruh signifikan terhadap kinerja guru dapat diterima.

Hasil penelitian ini sejalan dengan pendapat Kowaas, M. P., Sepang, J. L., \& Taroreh, R. N. (2016) dan Yakub, S., Tulim, A., 2013. Juga disampaikan oleh Hadiyati, H., Fatkhurahman, F., \& Suroto, B. (2017).

\section{KESIMPULAN DAN SARAN}

Berdasarkan hasil penelitian dan pembahasan, maka dapat diambil suatu kesimpulan bahwa variabel Motivasi dan disiplin kerja yang dialami oleh guru Sekolah Menengah Atas Negeri 11 Sijunjung berpengaruh secara positif dan signifikan terhadap kinerja guru pada Sekolah Menengah Atas Negeri 11 Sijunjung baik secara parsial maupun secara simultan.

\section{DAFTAR PUSTAKA}

A.A. Anwar Prabu Mangkunegara, 2008 Manajemen Sumber Daya Manusia,. Cetakan kelima, Penerbit PT. Remaja Rosdakarya. Bandung.

Dewi, S. P. (2012). Pengaruh pengendalian internal dan gaya kepemimpinan terhadap kinerja karyawan di SPBU (studi kasus pada SPBU anak cabang oerusahaan RB. Group). Jurnal Nominal, I(1). https://doi.org/10.1017/CBO97811 07415324.004.

Ghozali, Imam. 2012. "Aplikasi Analisis Multivariate dengan Program IBM SPSS. 20”. Semarang : Undip.

Hadiyati, H., Fatkhurahman, F., \& Suroto, B. (2017). Pelatihan Manajemen Penulisan Karya Tulis Ilmiah Bagi Tenaga Pendidik Di Smp N 3 Kampar Kiri Tengah. Dinamisia: Jurnal Pengabdian Kepada Masyarakat, 1(1, Des), 122-128.

Hasibuan, Malayu S.P. Drs. H. 2010. Manajemen Sumber Daya Manusia. Jakarta. PT Bumi Aksara.

Kowaas, M. P., Sepang, J. L., \& Taroreh, R. N. (2016). Pengaruh pendidikan, pelatihan dan disiplin kerja terhadap kinerja pegawai pada badan penanggulangan bencana daerah provinsi sulawesi utara the effect of education, trainning and work discipline on performance at department of regional disaster management agency north sulawesi. Jurnal Berkala Ilmiah Efisiensi, 16(3).

Riyadi, S. (1945). Pengaruh Kompensasi Finansial, Gaya Kepemimpinan , 


\section{Jurnal Ilmiah Ekonomi dan Bisnis}

Vol. 15. No. 2, September 2018: 150-164

EISSN : $2442-9813$

ISSN : $1829-9822$

dan Motivasi Kerja. Jurnal

Manajemen Dan Kewirausahaan,

13(1),

40-45.

https://doi.org/10.9744/jmk.13.1.

40-45

Safitri, E., Manajemen, J., \& Ekonomi, F. (1044). Pengaruh Pelatihan Dan Disiplin Kerja Terhadap Kinerja Karyawan. Jurnal Ilmiah Manajemen, 1(4).

Susanty, A., \& Baskoro, S. W. (2012). Pada Kinerja Karyawan (Studi Kasus Pada Pt . Pln (Persero ) Apd Semarang). Jati UNDIP, 7(2), 77-84.

Sugiyono, 2009, Metode Penelitian Kuantitatif, Kualitatif dan $R \& D$, Bandung : Alfabeta.

Yakub, S., Tulim, A., 2013, S., Kunci:, K., Kerja, D., Pendidikan, D., Kinerja, P. (n.d.). Pengaruh Disiplin Kerja, Pendidikan Dan Pelatihan Terhadap Kinerja Pegawai Pada Pt Kertas Kraft Aceh (Persero). 